\title{
HOW DOES FOREIGN DIRECT \\ INVESTMENT AFFECT ECONOMIC \\ GROWTH?
}

\author{
Eduardo Borensztein \\ José De Gregorio \\ Jong-Wha Lee
}

Working Paper No. 5057

\section{NATIONAL BUREAU OF ECONOMIC RESEARCH 1050 Massachusetts Avenue \\ Cambridge, MA 02138 \\ March 1995}

We wish to thank Robert Barro, Elhanan Helpman, Mohsin Khan, Se-Jik Kim, Donald Mathieson, Jeffrey Sachs, and Peter Wickham for useful comments. This paper was partially prepared while Jong-Wha Lee was at the Research Department, International Monetary Fund as a staff member and later as a visiting scholar. This paper is part of NBER's research programs in Growth and International Trade and Investment. Any opinions expressed are those of the authors and not those of the institutions with which the authors are affiliated, or the National Bureau of Economic Research.

() 1995 by Eduardo Borensztein, José De Gregorio and Jong-Wha Lee. All rights reserved. Short sections of text, not to exceed two paragraphs, may be quoted without explicit permission provided that full credit, including $\odot$ notice, is given to the source. 


\title{
HOW DOES FOREIGN DIRECT \\ INVESTMENT AFFECT ECONOMIC \\ GROWTH?
}

\begin{abstract}
We test the effect of foreign direct investment (FDI) on economic growth in a crosscountry regression framework, utilizing data on FDI flows from industrial countries to 69 developing countries over the last two decades. Our results suggest that FDI is an important vehicle for the transfer of technology, contributing relatively more to growth than domestic investment. However, the higher productivity of FDI holds only when the host country has a minimum threshold stock of human capital. In addition, FDI has the effect of increasing total investment in the economy more than one for one, which suggests the predominance of complementarity effects with domestic firms.
\end{abstract}

Eduardo Borensztein Central Asia Department International Monetary Fund 70019 th Street, NW Washington, DC 20431

Jong-Wha Lee

Economics Department

Korea University

Seoul, 136-701

KOREA and NBER
José De Gregorio

Research Department

International Monetary Fund

700 19th Street, NW

Washington, DC 20431 


\section{Introduction}

Technology diffusion plays a central role in the process of economic development. ${ }^{1}$ In contrast to the traditional Solow growth framework, where technological change is assumed to be exogenously given at the same rate for all countries, the recent growth literature has highlighted the dependence of growth rates on the state of domestic technology relative to that of the rest of the world. Thus, growth rates in developing countries are, in part, explained by a "catch-up" process in the level of technology. In a typical model of technology diffusion, the rate of economic growth of a backward country depends on the extent of the adoption and implementation of new technologies that are already in use in leading countries.

Technology diffusion can take place through a variety of channels that involve the transmission of ideas and new technologies. Imports of high-technology products, adoption of foreign technology and acquisition of human capital through international study are certainly important conduits for the international diffusion of technology. Besides these channels, foreign direct investment by multinational corporations (MNCs) is considered to be a major channel for the access to advanced technologies by developing countries. MNCs are among the most technologically advanced firms, accounting for a substantial part of the world's research and development $(R \& D)$ investment. Some recent work on economic growth has highlighted the role of foreign direct investment in the technological progress of developing countries. Findlay (1978) postulates that foreign direct investment increases the rate of technical progress in the

${ }^{1}$ Previous research on technology diffusion includes Nelson and Phelps (1966), Jovanovic and Rob (1989), Grossman and Helpman (1991, chapters 11 and 12), Segerstrom (1991) and Barro and Sala-i-Martin (1994, Ch.8). 
host country through a "contagion" effect from the more advanced technology, management practices, etc. used by the foreign firms. Wang (1990) incorporates this idea into a model more in line with the neoclassical growth framework, by assuming that the increase in "knowledge" applied to production is determined as a function of foreign direct investment (FDI).

The purpose of this paper is to examine empirically the role of FDI in the process of technology diffusion and economic growth in developing countries. We motivate the empirical work by a model of endogenous growth, in which the rate of technological progress is the main determinant of the long-term growth rate of income. Technological progress takes place through a process of "capital deepening" in the form of the introduction of new varieties of capital goods. MNCs possess more advanced "knowledge", which allows them to introduce new capital goods at lower cost. ${ }^{2}$ However, the application of this more advanced technologies also requires the presence of a sufficient level of human capital in the host economy. The stock of human capital in the host country, therefore, limits the absorptive capability of a developing country, as in Nelson and Phelps (1966), and Benhabib and Spiegel (1994). Hence, the model highlights the roles of both the introduction of more advanced technology and the requirement of absorptive capability in the host country as determinants of economic growth, and suggests the empirical investigation of the complementarity between FDI and human capital in the process of productivity growth.

\footnotetext{
${ }^{2}$ It is most likely that a foreign firm that decides to invest in another country enjoys lower costs than its domestic competitors deriving from higher productive efficiency. The higher efficiency may owe partly to the combination of foreign advanced management skills with domestic labor and inputs. Several micro-studies have attempted to assess empirically the impact of FDl on the domestic economy. (See, for example, Aitken and Harrison (1993) and references therein.)
} 
We test the effect of FDI on economic growth in a framework of cross-country regressions utilizing data on FDI flows from industrial countries to 69 developing countries over the last two decades. ${ }^{3}$ Our results suggest that FDI is in fact an important vehicle for the transfer of technology, contributing to growth in larger measure than domestic investment. Moreover, we find that there is a strong complementary effect between FDI and human capital, that is, the contribution of FDI to economic growth is enhanced by its interaction with the level of human capital in the host country. However, our empirical results imply that FDI is more productive than domestic investment only when the host country has a minimum threshold stock of human capital.

We also investigate the effect of FDI and domestic investment, namely, whether there is evidence that the inflow of foreign capital "crowds out" domestic investment. In principle, this effect could have either sign: by competing in product and financial markets MNCs may displace domestic firms; in contrast, FDI may favor the expansion of domestic firms by complementarity in production or by increasing their productivity through advanced technology spillover effects. Indeed, our results show a crowding-in effect, that is, a one-dollar increase in the net inflow of FDI is associated with an increase in total investment in the host economy of more than one dollar. The value of the point estimates place the total increase in investment at between 1.5 and 2.3 times the increase in the flow of FDI. Thus, in addition to its effect on technological progress, it appears that FDI contributes to economic growth by increasing total capital accumulation in the host economy.

${ }^{3}$ De Gregorio (1992) shows, in a panel data of 12 Latin American countries, that FDI is about three times more efficient than domestic investment. Blomstrom, Lipsey and Zejan (1992) also find a strong effect of FDI on economic growth in LDCs. 
The paper follows in four sections. Section II presents a theoretical framework to motivate our empirical investigation; section III provides an account of the data used in the empirical analysis; section IV describes the regression results, and section V presents some concluding remarks.

\section{Theoretical Framework}

We consider an economy where technical progress is the result of "capital deepening" in the form of an increase in the number of varieties of capital goods available, as in Romer (1990), Grossman and Helpman (1991) and Barro and Sala-i-Martin (1994). ${ }^{4}$ The economy produces a single consumption good according to the following technology:

$$
\mathrm{Y}_{\mathrm{t}}=\mathrm{AH}_{\mathrm{t}}^{\alpha} \mathrm{K}_{\mathrm{t}}^{1-\alpha}
$$

where A represents the exogenous state of technology, $\mathrm{H}$ denotes human capital, and $\mathrm{K}$ stands for physical capital. We assume that human capital $\mathrm{H}$ is a given endowment. Physical capital consists of an aggregate of different varieties of capital goods, and hence capital accumulation takes place through the expansion of the number of varieties.

Specifically, at each instant in time, the stock of domestic capital is given by:

$$
K=\left\{\int_{0}^{N} x(j)^{1-\alpha} d j\right\}^{\frac{1}{(1-\alpha)}}
$$

that is, total capital is a composite of different varieties of capital goods, each one being denoted

${ }^{4}$ We follow closely the speciflcation of Barro and Sala-i-Martin (1994, Ch. 6). 
by $x(j) .{ }^{5}$ We assume that the total number of varieties of capital goods, $N$, is produced by two types of firms: domestic and foreign firms present in the economy. The domestic firms produce $n$ varieties out of the total number $\mathbf{N}$, and the foreign firms produce $n^{*}$ varieties:

$$
\mathbf{N}=\mathrm{n}+\mathrm{n}^{*} \text {. }
$$

We assume that specialized firms produce each variety of capital good, and rent it out to final goods producers at a rental rate $m(j)$. The demand for each variety of capital good, $x(j)$, is given by the equality between the rental rate and the marginal productivity of the capital good in the production of the final good, that is:

$$
m(j)=A(1-\alpha) H^{\alpha} x(j)^{-\alpha}
$$

An expansion in the number of capital varieties requires the adaptation of technology available in more advanced countries that permits the introduction of a new type of capital goods. We assume that this process of technology adaptation is costly, requiring a fixed setup cost $F$ before production of the new type of capital can take place. We assume that the fixed setup cost depends negatively on the number of foreign firms operating in the host economy $\left(\mathrm{n}^{*}\right)$. This assumption is made to capture the notion that foreign firms bring to the developing economy an advance in "knowledge" applicable to the production of new capital goods that may be already available in other countries. Thus, foreign direct investment is the main channel of technological progress in this framework, by making it easier to adopt the technology of producing new capital varieties. In addition, there is a "catch-up" effect in technological progress, by which the setup cost depends negatively on how many varieties are produced

\footnotetext{
${ }^{5}$ This formulation is due to Ethier (1982).
} 
domestically compared to those produced in the more advanced countries (which we denote by $\mathrm{N}^{*}$ ), since it is cheaper to imitate products already in existence for some time than products at the frontier of innovation. ${ }^{6}$ Thus, we postulate the following functional form for the setup cost:

$$
\mathrm{F}=\mathrm{F}\left(\mathrm{n}^{*}, \mathrm{~N} / \mathrm{N}^{*}\right) \text {, where } \frac{\partial \mathrm{F}}{\partial \mathrm{n}^{*}}<0 \text { and } \frac{\partial \mathrm{F}}{\partial\left(\mathrm{N} / \mathrm{N}^{*}\right)}<0
$$

An alternative interpretation of (5) can be given in terms of "quality ladders," as in Grossman and Helpman (1991). The increase in the number of varieties could be interpreted as an improvement in the quality of existing goods. Therefore, the presence of MNCs would reduce the cost of improving the quality of existing capital goods, generating the same negative relationship between foreign direct investment and setup costs. Moreover, the catch-up assumption could be reinterpreted as meaning that the cost of improving an existing capital good is smaller the lowest is its quality. That is, upgrading an old typewriter is cheaper than upgrading a personal computer.

In addition to the fixed setup cost, once a capital good is introduced, the owner must spend a constant maintenance cost per period of time. This is analogous to assume that there is a constant marginal cost of production of $x(j)$ equal to 1 , and that capital goods depreciate fully. Assuming a steady state where the interest rate (r) is constant, profits for the producer of a new variety of capital $j$ are:

${ }^{6}$ The importance of the "technology gap" as a determinant of technological diffusion has been stressed in previous research, for example, Nelson and Phelps (1966). 


$$
\Pi(j)_{t}=-F\left(n{ }^{*}, N_{t} / N^{*}{ }_{1}\right)+\int_{1}^{\infty}[m(j) x(j)-x(j)] e^{-r(s-t)} d s
$$

Maximization of equation (6) subject to the demand equation (4) generates the following equilibrium level for the production of each capital $\operatorname{good} x(j)$ :

$$
x(j)=H A^{1 / \alpha}(1-\alpha)^{2 / \alpha}
$$

Note that $x(j)$ is independent of time, that is, at each instant the level of production of each new good is the same. Moreover, the level of production across the different varieties is also the same due to the symmetry among producers. Substituting equation (7) into the demand function (4), we obtain the following expression for the rental rate:

$$
m(j)=1 /(1-\alpha),
$$

which gives the rental rate as a markup over maintenance costs.

Finally, we assume that there is free entry, and hence, the rate of return $r$ will be such that profits are equal to zero. Solving for the zero profits condition we obtain:

$$
r=\Psi F\left(n^{*}, N / N^{*}\right)^{-1} H
$$

where

$$
\Psi=\mathrm{A}^{1 / \alpha} \alpha(1-\alpha)^{(2-\alpha) / \alpha}
$$

To close the model, we need to describe the process of capital accumulation, which is 
driven by savings behavior. ${ }^{7}$ We assume that individuals maximize the following standard intertemporal utility function:

$$
U_{t}=\int_{t}^{\infty} \frac{C_{s}^{1-\sigma}}{1-\sigma} e^{-\rho(s-t)} d s
$$

where $\mathrm{C}$ denotes units of consumption of the final good $\mathrm{Y}$. Given a rate of return equal to $\mathrm{r}$, the optimal consumption path is given by the standard condition:

$$
\frac{\dot{C}_{t}}{\mathrm{C}_{\mathrm{t}}}=\frac{1}{\sigma}(\mathrm{r}-\rho)
$$

It is easy to verify that the rate of growth of consumption must, in a steady state equilibrium, equal to the rate of growth of output, which we denote by $\mathrm{g}$.

Finally, substituting equation (9) into equation (11), we obtain the following expression for the rate of growth of the economy:

$$
g=\frac{1}{\sigma}\left[\Psi F\left(n^{*}, N / N^{*}\right)^{-1} H-\rho\right]
$$

Equation (12) shows that foreign direct investment, which is measured by the number of products produced by foreign firms $\left(\mathrm{n}^{*}\right)$, reduces the costs of introducing new varieties of capital goods, thus increasing the rate at which new capital goods are introduced. The cost of introducing new capital goods is also smaller for more backward countries; that is, countries that produce fewer varieties of capital goods than the leading countries--countries with lower $\mathbf{N} / \mathbf{N}^{*}-$ -

\footnotetext{
${ }^{7}$ Although there is no international trade in this model, this is not a closed economy because of the presence of foreign firms. However, with the proportion of foreign firms remaining constant in a steady-state situation, equilibrium conditions are analogous to those prevailing in a closed economy.
} 
enjoy lower costs of adoption of technology, and will tend to grow faster. Furthermore, the effect of FDI on the growth rate of the economy is positively associated with the level of human capital, that is, the higher the level of human capital in the host country, the higher the effect of FDI on the growth rate of the economy. ${ }^{8}$

To implement empirically the model we estimate the following approximation to equation (12):

$$
\mathrm{g}=\mathrm{c}_{0}+\mathrm{c}_{1} \mathrm{FDI}+\mathrm{c}_{2} \mathrm{FDI} \times \mathrm{H}+\mathrm{c}_{3} \mathrm{H}+\mathrm{c}_{4} \mathrm{Y}_{0}+\mathrm{c}_{6} \mathrm{X}
$$

where FDI is foreign direct investment, $\mathrm{H}$ the stock of human capital, $\mathrm{Y}_{0}$ initial GDP per capita, and $\mathrm{X}$ a set of other variables that are frequently included as determinants of growth in crosscountry studies, such as government consumption and variables representing foreign exchange and trade distortions.

\section{Data}

There are several sources for data on foreign direct investment. The IMF provides data on net (International Financial Statistics) and gross foreign direct investment (Balance of Payments Statistics), where the former refers to inflows net of outflows, and the latter refers only to inflows, that is, foreign direct investment into the country. OECD statistics (Geographical Distribution of Financial Flows to Developing Countries) tally FDI originated in

\footnotetext{
${ }^{8}$ Romer (1993) finds a positive interaction effect between secondary school enrollment and imports of machinery. Cohen (1993) also finds a positive interaction between human capital and access to foreign financing in general for developing countries. This model may then provide a rationale for those findings, at least as far as the FDI component of imports of machinery and foreign financing is concerned. Finally, Romer (1993) also finds threshold effects for his interaction term similar to those we report in Section IV.
} 
OECD member countries into developing economies. The choice between these alternatives depends on which data set would correspond more closely to the FDI effect we are trying to uncover.

In the first place, it seems more appropriate to use gross data because we are interested in the benefits that foreign direct investment may have in the host country via transfer of knowledge and other spillover effects; in addition, the outflow of foreign direct investment does not involve negative growth effects for the source country. In the second place, in our framework, foreign direct investment flows from industrialized to developing countries to close the technological gap. Foreign direct investment taking place between countries with roughly the same level of technological development may respond to a large extent to other factors, including global firm strategy and market penetration, for example to allow firms to circumvent trade restrictions and offset other advantages accorded to domestic producers. This type of foreign direct investment flows may not be expected to display higher than average productivity. For this reason our empirical work focuses only on foreign direct investment received by developing countries. And furthermore, since flows of foreign direct investment between developing countries may also respond to trade and tax policy incentives to a larger extent than to a technological gap, we also exclude those flows. Therefore, the OECD measure of foreign direct investment, while having a partial coverage, appears to be the most appropriate for our purposes. ${ }^{9}$ These data are available on a yearly basis from 1970 to 1989.

${ }^{9}$ Since balance of payments data from Balance of Payments Statistics do not provide information about the country of origin, it cannot be adjusted to include flows from industrial countries only. There are, in fact, significant differences between overall gross foreign direct investment in developing countries and foreign direct investment originated in OECD countries (OECD data). The correlation between these two measures, although positive, is weak (the 
National accounts data, such as growth rate of income, initial income and government consumption, come from Summers and Heston (release 5.5 of June 1993) which provides data up to 1989 . This allows us to consider a 20 -year period for the empirical investigation. The growth rate measure is the annual rate of per capita real GDP. Government consumption is measured by the average share of real government consumption in real GDP. FDI is also measured as a proportion of GDP.

For the human capital stock variable we use the initial level of average years of the male secondary schooling constructed by Barro and Lee (1993). According to Barro and Lee (1994), this measure of educational attainment is the one most significantly correlated with growth. Data for the other explanatory variables, such as the domestic investment rate, and the foreign exchange parallel market premium are also from Barro and Lee (1994).

\section{Results}

The purpose of our empirical investigation is to estimate the effects of FDI on economic growth, and to investigate the channel through which FDI may be beneficial for growth. In particular, as discussed in section II, we examine whether FDI interacts with the stock of human capital to affect growth rates. We also test whether the level of FDI has an effect on the overall level of investment in the country and on the efficiency of investment.

The main regression results indicate that FDI has a positive overall effect on economic growth, although the magnitude of this effect depends on the stock of human capital available in the host economy. The cross-country regressions also show that FDI exerts a positive effect 
on domestic investment, presumably because the attraction of complementary activities dominates the displacement of domestic competitors. This is an indirect effect of FDI on growth, since it operates through "pulling in" other sources of investment. Finally, the direct effect of FDI may be quite different for countries with different levels of human capital, and, in fact, for countries with very low levels of human capital the direct effect is negative. All regressions are based on panel data for the two decades 1970-79 and 1980-89, and were estimated using the seemingly unrelated regressions technique (SUR). We do not report cross-section regressions, which basically yield the same qualitative results as those of the panel estimation. The final sample consists of 69 developing countries, for which data on all the variables are available.

Table 1 reveals several interesting results for the effects of FDI on economic growth. Regression 1.1 shows that FDI has a positive impact on economic growth. Although the coefficient is marginally significant it indicates that for each percentage point of increase in the FDI-to-GDP ratio, the rate of growth of the host economy increases by 0.8 percentage points. Inclusion of the interaction between FDI and human capital improves the overall performance of the regression. The specification in regression 1.2 replaces the FDI variable by the product between FDI and human capital, and yields a coefficient that is positive and statistically highly significant. While this specification follows closely from the framework developed in section II, the significance of the interaction term may be the result of the omission of other relevant factors, in particular, the FDI variable by itself. Thus, it is necessary to include FDI and secondary school attainment (our measure of human capital) individually alongside their product. In that way, we can test jointly whether these variables affect growth by themselves or through the interaction term. Such specification is adopted in regression 1.3, which shows that the 
coefficient on FDI is negative, although insignificant, while the interaction term is positive. The values of these regression coefficients indicate that all countries with secondary school attainment above $0.45^{10}$ will benefit positively from FDI. In our sample, 48 out of the 69 countries satisfy this threshold in 1980 .

We have also explored the interaction of FDI with indicators of distortions in the trade regime, as measured by tariffs, and in the capital account of the balance of payments, which was proxied by the parallel market premium for foreign exchange. In both cases, however, the interaction term was not statistically significant. Thus, this type of distortion does not appear to have affected the nature of FDI flows in a significant way, at least as far as can be detected in this sample. We also incorporated in the regression an interaction term between human capital and initial income as suggested by the model, where the speed of convergence is increasing in the level of human capital, but the coefficient was not significant.

Regressions 1.4 to 1.6 include variables proxying for foreign exchange market distortions and continental dummies. ${ }^{11}$ Our main findings are robust to these specifications; in addition, as expected, the parallel market premium is negatively correlated with growth, and the African and Latin American dummies are negative. The same results are also obtained when government expenditure is omitted from the regression. The threshold for secondary school attainment, from

\footnotetext{
${ }^{10}$ Meaning a male population above 25 years with an average of 0.45 years of secondary schooling. An example of an economy with secondary school attainment of 0.45 is the following: only 10 percent of the population above 25 years of age has ever attended secondary school; out of this group, only 50 percent completed secondary school (6 years), with the remaining going only through the first cycle ( 3 years). Then, secondary school attainment is $0.1 \times[3 \times 0.5+6 \times 0.5]+0.9 \times 0=0.45$.

${ }^{11}$ We have also included the average level of tariffs as one of the regressors, but it was not significantly different from zero.
} 
which FDI starts having positive effects, changes only slightly with these different specifications, reaching a maximum value of 0.73 , which is satisfied by 38 countries in the sample.

Overall, the results from the regressions displayed in Table 1 show strong complementary effects between FDI and human capital on the growth rate of income. This result is consistent with the idea that the flow of advanced technology brought along by FDI can increase the growth rate of the host economy only by interacting with that country's absorptive capability.

The contribution of FDI to economic growth could result from two effects. First, FDI could add to capital accumulation, and thus to economic growth. This would require that FDI does not "crowd out" equal amounts of investment from domestic sources by competing in product markets or financial markets (for example, under conditions of financial repression). And second, FDI could contribute to economic growth if it is more productive, or efficient, than domestic investment.

To investigate these issues, we first analyze the effects of FDI on total fixed investment. The results, presented in Table 2, show that FDI increases investment more than one-to-one, irrespective of the specification adopted. Since data on total investment include FDI, if FDI does not affect the total level of investment we would obtain the estimated coefficient on FDI equal to one. The coefficient on FDI, in fact, ranges from 1.5 to 2.3 (when interaction terms are not included) according to the particular specification, with the lower values obtaining when continental dummies were included. The interaction between FDI and human capital turned out to be statistically insignificant for the determination of total investment (regression 2.2). Overall, these results imply that FDI actually stimulates domestic investment.

To explore the question of possible higher efficiency of FDI, we test whether FDI has 
effects over and above aggregate investment in the growth equations. The results, displayed in Table 3, indicate that the contribution of FDI to growth is evident only when the interaction between human capital and FDI is included. In this case, the values of the coefficients imply that the threshold level of education for which the effects of FDI turn positive (above its effects on investment) is 0.83 , which is satisfied by 32 countries in the sample. Note, however, that countries with school attainment below 0.83 still benefit from FDI through its crowding-in effects on domestic investment, which is confirmed by the estimates of the total FDI effect on growth reported above in Table 1 indicating that the threshold for positive effects is a minimum school attainment index equal to 0.45 .

In order to investigate whether the interaction effect is unique to foreign investment, rather than applying to investment from all sources, we have also added an interaction term between aggregate investment and secondary school attainment. In regression 3.7, reported in Table 3, the interaction term between aggregate investment and human capital is not statistically significant, while the rest of the coefficients are very similar to those specifications where this term is not included. Therefore, we can conclude that the interaction between human capital and investment is a particular characteristic of FDI.

It should be noticed that the cross-country regressions presented here may be subject to endogeneity problems. The correlation between FDI and growth rate could arise from an endogenous determination of FDI, that is, FDI itself is likely to be influenced by innovations in the stochastic process governing growth rates. For instance, institutional factors that raise rates of return on capital will certainly increase both the growth rate and the inflow of foreign 
direct investment simultaneously. ${ }^{12}$ In this circumstances, there will exist a correlation between FDI and the country-specific error term, which biases the estimated coefficients.

Although, in principle, the endogeneity problem can be avoided by applying instrumental variable techniques, the fundamental problem is that there are no ideal instruments available. A good instrument would be a variable which is highly correlated with FDI but yet not with the error term in these regressions. Nevertheless, we have tried to control for the endogeneity problem by using as instruments the initial and lagged values of FDI and a East Asian continental dummy, with results reported in Table $4 .{ }^{13}$ Regressions 4.1 and 4.2 show that the instrumental variable estimation yields results very similar to those obtained by SUR estimation. The estimated coefficients on FDI are still significantly negative, and the interactive term with human capital is significantly positive. We also carried out the instrumental variable estimation on a cross-sectional sample for the period 1975-85, which is reported in regressions 4.3 and 4.4 . In this case, we used lagged values of FDI over the period 1970-74, and the East Asian dummy as instruments. The FDI and the FDI interactive terms become somewhat less significant, although they are still jointly significant. Overall, the evidence presented in Table 4 seems to indicate that the endogeneity problem may not be too serious.

The estimated regressions permit to quantify the total impact of FDI on economic growth.

\footnotetext{
${ }^{12}$ See Edwards (1990) for a discussion on the determination of foreign direct investment in LDCs.

${ }^{13}$ Because the data on FDI are available only from 1970, we have used the initial value of FDI over the period $1970-72$ as an instrument for the first decade. For the second decade, the lagged value of FDI over the period 1975-80 was used as an instrument. The East Asian dummy is chosen as an instrument considering that it is not significant when added as an additional explanatory variable into the growth regressions 1.4 or 3.6.
} 
The results of computing the effect of an increase of 1 percentage point in the FDI to GDP ratio on per-capita growth, as a function of secondary school attaintment, are presented in Figure 1. Two methods can be followed. In the first one, we computed the direct effect of FDI on the productivity of investment using equation 3.3 (denoted as I), and the indirect effect through the crowding-in of domestic investment, obtained from equations 2.2 and 3.3 (denoted as II). The total from this calculation is line III. Although in regressions 2.2 the coefficient on the interaction term is negative, but not significant, we use that point estimate to provide a conservative assessment (or lower bound) of the effects of FDI on growth. The second method computes directly the total effect from equation 1.3 (line IV). We also include the point estimate of the negative but statistically insignificant coefficient on FDI obtained in regression 1.3.

The results are broadly similar in both cases, although the direct regression produces somewhat larger effects of FDI on growth, about 0.3 percentage points higher for each given level of school attainment. The results indicate that starting from school attainment of 0.45 (48 countries in the sample), or at most 0.62 (41 countries in the sample), FDI has positive effects on growth. The total effect amounts to between 0.4 and 0.7 percentage points for the average level of secondary school attainment for the countries in the sample $(0.9)$, which is well above the less than 0.15 percentage points increase in the growth rate generated by each percentage point increase in aggregate investment (as estimated in the regressions reported in Table 3). Separating between investment and efficiency effects, the figure shows that the former becomes more important at high levels of human capital. This is a mere reflection of our finding that the interaction term between FDI and schooling is more relevant for the efficiency, rather than the volume, of investment. 


\section{Conclusions}

There is a good a priori case to presume that FDI is more productive than domestic investment. As Graham and Krugman (1991) argue, domestic firms have better knowledge and access to domestic markets; if a foreign firm decides to enter the market, it must compensate for those advantages of domestic firms. It is most likely that a foreign firm that decides to invest in another country enjoys lower costs than its domestic competitors deriving from higher productive efficiency. ${ }^{14}$ In the case of developing countries in particular, it is likely that the higher efficiency of FDI would owe to the combination of advanced management skills and technology with domestic labor and inputs; FDI may be the main channel through which advanced technology is transferred to developing countries.

Different types of distortions, however, may jeopardize the above role of FDI as a means for advanced technology transfer. For example, because of protectionist trade policies, FDI may be the only way to access domestic markets by firms that would otherwise export the products to the host country. Similarly, governments may offer a set of incentives to foreign investors to stimulate the inflow of FDI, with the objective of increasing foreign exchange reserves or of developing certain sectors considered strategic from an industrial policy viewpoint. The effect of these policies may be a flow of FDI that does not respond to higher efficiency but only to profit opportunities created by distorted markets. These considerations make the empirical evaluation of the performance of FDI an appealing question.

The most robust finding of this paper is that the effect of FDI on economic growth is

\footnotetext{
${ }^{14}$ See, for example, Aitken and Harrison (1993) and references therein, on microeconomic studies of the efficiency of FDI.
} 
dependent on the level of human capital available in the host economy. There is a strong positive interaction between FDI and the level of educational attainment (our proxy for human capital) in our sample that considers FDI from industrial country sources into developing countries. Notably, the same interaction is not significant in the case of domestic investment. The contribution of FDI to economic growth comprises two effects. First, FDI increases the overall level of investment, attracting higher levels of domestic investment. This effect is not enhanced by the interaction with human capital. And second, FDI is more productive than domestic investment, a result that does depend on the interaction with human capital.

Some caution must be exercised, however, in the interpretation of the size of the effect on economic growth of FDI. Our data measures the international flow of resources for foreign direct investment, as recorded in balance of payments statistics. This is, however, only part of the resources invested by a multinational, because a significant part of investment may be financed through debt or equity issues raised in the domestic market. Thus, our measure of FDI underestimates the total value of fixed investment made by a multinational firm and the coefficients on FDI may be proportionally overestimated. ${ }^{15}$ To the extent that this bias in the measure of FDI is uniform across countries and over time, the qualitative results are not affected.

This paper emphasizes the interactions between human capital and the efficiency of FDI, and shows empirically that FDI has positive effects on economic growth when the level of education is higher than a given threshold. However, it does not explore the reverse connection, namely, the effects of FDI on the level of human capital. As we have argued above,

\footnotetext{
${ }^{15}$ Similarly, the crowding-in effect of FDI is overestimated.
} 
FDI is a vehicle for the adoption of new technologies, and therefore, the training required to prepare the labor force to work with new technologies suggests that there may also be an effect of FDI on human capital accumulation, an issue that is left for further research. 


\section{$\underline{\text { References }}$}

Aitken, Brian and Anne Harrison, "Do Domestically-Owned Firms Benefit from Foreign Direct Investment: Evidence from Panel Data, " Unpublished manuscript, International Monetary Fund, 1993.

Barro, Robert and Jong-Wha Lee, "International Comparisons of Educational Attainment," Journal of Monetary Economics, 32 (December 1993), pp. 361-394.

Barro, Robert and Jong-Wha Lee, "Sources of Economic Growth" Carnegie Rochester Conference Series on Public Policy, 40 (June 1994), pp. 1-46.

Barro, Robert and Xavier Sala-i-Martin, Economic Growth, (Cambridge, MA: McGraw-Hill, 1994).

Benhabib, Jess and Mark Spiegel, "The Roles of Human Capital in Economic Development: Evidence from Aggregate Cross-Country Data," Journal of Monetary Economics, 34 (October 1992), pp. 143-173.

Blomstrom, Magnus, Robert Lipsey and Mario Zejan, "What Explains Developing Country Growth," NBER Working Paper No. 4132, August 1992.

Cohen, Daniel, "Foreign Finance and Economic Growth. An Empirical Analysis, " Unpublished Manuscript, CEPREMAP, May 1993.

De Gregorio, José, "Economic Growth in Latin America," Journal of Development Economics, 39 (July 1992), pp. 58-84.

Edwards, Sebastian, "Capital Flows, Foreign Direct Investment, and Debt-Equity Swaps in Developing Countries, " NBER Working Paper No. 3497, October 1990.

Ethier, Wilfred J. "National and International Returns to Scale in the Modern Theory of International Trade," American Economic Review, 72 (1982), pp. 389-405.

Findlay, Ronald, "Relative Backwardness, Direct Foreign Investment, and The Transfer of Technology: A Simple Dynamic Model, "Quarterly Journal of Economics, 92 (February 1978), pp. 1-16.

Grossman, Gene and Elhanan Helpman, Innovation and Growth in the Global Economy, (Cambridge, MA: MIT Press, 1991).

Graham, Edward and Paul Krugman, Foreign Direct Investment in the United States, (Washington, DC: Institute for International Economics, 1991). 
Jovanovic, Boyan and Rafael Rob, "Growth and Diffusion of Technology, " Review of Economic Studies, Vol. 56 (October 1989), pp. 569-582.

Nelson, Richard, and Edmund Phelps, "Investment in Humans, Technological Diffusion, And Economic Growth," American Economic Review: Papers and Proceedings, 61 (May 1996) pp. 69-75.

Romer, Paul, "Endogenous Technological Change," Journal of Political Economy, Vol. 98. (October 1990), pp.S71-S102.

Romer, Paul, "Idea Gaps and Object Gaps in Economic Development," Journal of Monetary Economics, Vol 32 (December 1993), pp. 543-573.

Segerstrom, Paul S., "Innovation, Imitation, and Economic Growth," Journal of Political Economy, Vol. 99 (August 1991), pp. 807-827.

Summers, Robert, and Alan Heston, "The Penn World Table (Mark 5): An Expanded Set of International Comparisons. 1950-1988, " Quarterly Journal of Economics, Vol. 106 (May 1991), pp. 327-368.

Wang, Jian-Ye, "Growth, Technology Transfer, and The Long-Run Theory of International Capital Movements," Journal of International Economics, 29 (1990) pp. 255-271. 
Table 1. FDI and Per Capita GDP Growth: Panel of Two Decades (1970-89)

\begin{tabular}{|c|c|c|c|c|c|c|}
\hline $\begin{array}{l}\text { Independent } \\
\text { Variable } \\
\text { Regression Number }\end{array}$ & 1.1 & 1.2 & $\begin{array}{l}\text { Coef } \\
\text { S Standa }\end{array}$ & $\begin{array}{l}\text { cient } \\
\text { errors) }\end{array}$ & 1.5 & 1.6 \\
\hline $\log ($ initial GDP) & $\begin{array}{l}-0.0110 \\
(0.0042)\end{array}$ & $\begin{array}{l}-0.0112 \\
(0.0041)\end{array}$ & $\begin{array}{l}-0.0108 \\
(0.0041)\end{array}$ & $\begin{array}{l}-0.0122 \\
(0.0039)\end{array}$ & $\begin{array}{l}-0.0077 \\
(0.0045)\end{array}$ & $\begin{array}{l}-0.0100 \\
(0.0041)\end{array}$ \\
\hline Schooling & $\begin{array}{c}0.0166 \\
(0.0047)\end{array}$ & $\begin{array}{c}0.0141 \\
(0.0046)\end{array}$ & $\begin{array}{c}0.0129 \\
(0.0048)\end{array}$ & $\begin{array}{c}0.0128 \\
(0.0045)\end{array}$ & $\begin{array}{c}0.0074 \\
(0.0046)\end{array}$ & $\begin{array}{l}0.00778 \\
(0.0044)\end{array}$ \\
\hline $\begin{array}{l}\text { Government } \\
\text { consumption }\end{array}$ & $\begin{array}{l}-0.1030 \\
(0.0360)\end{array}$ & $\begin{array}{l}-0.0923 \\
(0.0352)\end{array}$ & $\begin{array}{l}-0.0880 \\
(0.0356)\end{array}$ & $\begin{array}{l}-0.0811 \\
(0.0333)\end{array}$ & $\begin{array}{l}-0.0911 \\
(0.0344)\end{array}$ & $\begin{array}{l}-0.0818 \\
(0.0326)\end{array}$ \\
\hline FDI & $\begin{array}{c}0.8438 \\
(0.4820)\end{array}$ & & $\begin{array}{l}-0.7181 \\
(0.7678)\end{array}$ & $\begin{array}{l}-0.8489 \\
(0.7203)\end{array}$ & $\begin{array}{l}-0.9154 \\
(0.7300)\end{array}$ & $\begin{array}{l}-1.0190 \\
(0.6883)\end{array}$ \\
\hline FDI* schooling & & $\begin{array}{l}1.1428 \\
(0.3879\end{array}$ & $\begin{array}{c}1.6111 \\
(0.6320)\end{array}$ & $\begin{array}{l}1.6231 \\
(0.6086)\end{array}$ & $\begin{array}{c}1.3435 \\
(0.5908)\end{array}$ & $\begin{array}{l}1.3891 \\
(0.5715)\end{array}$ \\
\hline $\begin{array}{l}\text { Log }(1+b 1 \text { ack } \\
\text { market premium) }\end{array}$ & & & & $\begin{array}{l}-0.0185 \\
(0.0054)\end{array}$ & & $\begin{array}{l}-0.0188 \\
(0.0060)\end{array}$ \\
\hline $\begin{array}{l}\text { Sub-Saharan } \\
\text { African dummy }\end{array}$ & & & & & $\begin{array}{l}-0.0187 \\
(0.0064)\end{array}$ & $\begin{array}{l}-0.0202 \\
(0.0057)\end{array}$ \\
\hline $\begin{array}{l}\text { Latin America } \\
\text { dummy }\end{array}$ & & & & & $\begin{array}{c}-0.0231 \\
(0.0060)\end{array}$ & $\begin{array}{l}-0.0202 \\
(0.0057)\end{array}$ \\
\hline $\begin{array}{l}\mathbf{R}^{2} \text {, Individual } \\
\text { periods } \\
\text { (No. obs.) }\end{array}$ & $\begin{array}{ll}0.19 & (69) \\
0.18 & (69)\end{array}$ & $\begin{array}{ll}0.24 & (69) \\
0.20 & (69)\end{array}$ & $\begin{array}{ll}0.25 & (69) \\
0.19 & (69)\end{array}$ & $\begin{array}{ll}0.39 & (69) \\
0.16 & (69)\end{array}$ & $\begin{array}{ll}0.28 & (69) \\
0.36 & (69)\end{array}$ & $\begin{array}{ll}0.42 & (69) \\
0.32 & (69)\end{array}$ \\
\hline
\end{tabular}

Notes: separate constants are estimated for each period. Other constants are constrained to be the same for all periods. Foreign Direct Investment (FDI) is an inflow from OECD countries to each country as a share in the current PPP-adjusted GDP from Summers and Heston v.5.5 (1991). Schooling is the secondary educational attainment of male population aged 25 and over from Barro and Lee (1993). 
Table 2. FDI and Aggregate Investment Rates: Panel of Two Decades (1970-89)

\begin{tabular}{|c|c|c|c|c|}
\hline $\begin{array}{l}\text { Independent } \\
\text { Variable } \\
\text { Regression Number }\end{array}$ & \multicolumn{4}{|c|}{$\begin{array}{c}\text { Coefficient } \\
\text { (Standard errorg) }\end{array}$} \\
\hline Log (initial GDP) & $\begin{array}{c}0.0356 \\
(0.0101)\end{array}$ & $\begin{array}{c}0.0355 \\
(0.0101)\end{array}$ & $\begin{array}{c}0.0346 \\
(0.0102)\end{array}$ & $\begin{array}{c}0.0368 \\
(0.0103)\end{array}$ \\
\hline Schooling & $\begin{array}{c}0.0197 \\
(0.0110)\end{array}$ & $\begin{array}{c}0.0209 \\
(0.0113)\end{array}$ & $\begin{array}{c}0.0197 \\
(0.0109)\end{array}$ & $\begin{array}{c}0.0044 \\
(0.0106)\end{array}$ \\
\hline $\begin{array}{l}\text { Government } \\
\text { consumption }\end{array}$ & $\begin{array}{l}-0.1243 \\
(0.0878)\end{array}$ & $\begin{array}{l}-0.1304 \\
(0.0890)\end{array}$ & $\begin{array}{l}-0.1217 \\
(0.0876)\end{array}$ & $\begin{array}{l}-0.1400 \\
(0.0844)\end{array}$ \\
\hline FDI & $\begin{array}{c}2.3135 \\
(0.9904)\end{array}$ & $\begin{array}{c}2.7959 \\
(1.6251)\end{array}$ & $\begin{array}{c}2.2944 \\
(0.9919)\end{array}$ & $\begin{array}{c}1.5346 \\
(0.9470)\end{array}$ \\
\hline FDI* schooling & & $\begin{array}{l}-0.4708 \\
(1.2919)\end{array}$ & & \\
\hline $\begin{array}{l}\text { Log ( } 1+\text { black } \\
\text { market premium) }\end{array}$ & & & $\begin{array}{l}-0.0078 \\
(0.0118)\end{array}$ & \\
\hline $\begin{array}{l}\text { Sub-Saharan } \\
\text { African dummy }\end{array}$ & & & & $\begin{array}{l}-0.0644 \\
(0.0173)\end{array}$ \\
\hline $\begin{array}{l}\text { Latin America } \\
\text { dummy }\end{array}$ & & & & $\begin{array}{l}-0.0655 \\
(0.0158)\end{array}$ \\
\hline $\begin{array}{l}\mathbf{R}^{2} \text {, Individual } \\
\text { periods } \\
\text { (No. obs.) }\end{array}$ & $\begin{array}{ll}0.28 & (69) \\
0.47 & (69)\end{array}$ & $\begin{array}{ll}0.28 & (69) \\
0.48 & (69)\end{array}$ & $\begin{array}{ll}0.29 & (69) \\
0.48 & (69)\end{array}$ & $\begin{array}{ll}0.32 & (69) \\
0.60 & (69)\end{array}$ \\
\hline
\end{tabular}

Notes: See Table 1. 
Table 3. Per Capita GDP Growth: Productivity of FDI and Domestic Investment

\begin{tabular}{|c|c|c|c|c|c|c|c|}
\hline \multirow{2}{*}{$\begin{array}{l}\text { Independent } \\
\text { Variable } \\
\text { Regression Number }\end{array}$} & \multicolumn{7}{|c|}{$\begin{array}{c}\text { Coefficient } \\
\text { (standard errors) }\end{array}$} \\
\hline & 3.1 & 3.2 & 3.3 & 3.4 & 3.5 & 3.6 & 3.7 \\
\hline Investment rate & $\begin{array}{c}0.1496 \\
(0.0339)\end{array}$ & $\begin{array}{c}0.1386 \\
(0.0325)\end{array}$ & $\begin{array}{c}0.1526 \\
(0.0326)\end{array}$ & $\begin{array}{c}0.1415 \\
(0.0307)\end{array}$ & $\begin{array}{c}0.1196 \\
(0.0337)\end{array}$ & $\begin{array}{c}0.1120 \\
(0.0317)\end{array}$ & $\begin{array}{c}0.1357 \\
(0.0457)\end{array}$ \\
\hline $\log ($ initial GDP) & $\begin{array}{c}-0.0156 \\
(0.0040)\end{array}$ & $\begin{array}{l}-0.0159 \\
(0.0039)\end{array}$ & $\begin{array}{l}-0.0154 \\
(0.0038)\end{array}$ & $\begin{array}{l}-0.0165 \\
(0.0036)\end{array}$ & $\begin{array}{l}-0.0117 \\
(0.0041)\end{array}$ & $\begin{array}{l}-0.0137 \\
(0.0040)\end{array}$ & $\begin{array}{l}-0.0150 \\
(0.0039)\end{array}$ \\
\hline Schooling & $\begin{array}{c}0.0133 \\
(0.0043)\end{array}$ & $\begin{array}{l}0.0120 \\
(0.0042)\end{array}$ & $\begin{array}{c}0.0094 \\
(0.0043)\end{array}$ & $\begin{array}{c}0.0098 \\
(0.0041)\end{array}$ & $\begin{array}{c}0.0063 \\
(0.0043)\end{array}$ & $\begin{array}{c}0.0069 \\
(0.0040)\end{array}$ & $\begin{array}{c}0.0052 \\
(0.0091)\end{array}$ \\
\hline $\begin{array}{l}\text { Government } \\
\text { consumption }\end{array}$ & $\begin{array}{l}-0.0879 \\
(0.0325)\end{array}$ & $\begin{array}{l}-0.0809 \\
(0.0319)\end{array}$ & $\begin{array}{c}-0.0702 \\
(0.0317)\end{array}$ & $\begin{array}{l}-0.0663 \\
(0.0299)\end{array}$ & $\begin{array}{c}-0.0782 \\
(0.0321)\end{array}$ & $\begin{array}{l}-0.0711 \\
(0.0303)\end{array}$ & $\begin{array}{l}-0.0710 \\
(0.0319)\end{array}$ \\
\hline FDI & $\begin{array}{c}0.2252 \\
(0.4679)\end{array}$ & & $\begin{array}{l}-1.4063 \\
(0.7185)\end{array}$ & $\begin{array}{l}-1.4607 \\
(0.6728)\end{array}$ & $\begin{array}{l}-1.4407 \\
(0.7013)\end{array}$ & $\begin{array}{l}-1.4928 \\
(0.6581)\end{array}$ & $\begin{array}{l}-1.3531 \\
(0.7255)\end{array}$ \\
\hline FDI*schooling & & $\begin{array}{l}0.8025 \\
(0.3681)\end{array}$ & $\begin{array}{l}1.6801 \\
(0.5778)\end{array}$ & $\begin{array}{c}1.6473 \\
(0.5555)\end{array}$ & $\begin{array}{c}1.4914 \\
(0.5619)\end{array}$ & $\begin{array}{c}1.4853 \\
(0.5415)\end{array}$ & $\begin{array}{c}1.5923 \\
(0.5994)\end{array}$ \\
\hline $\begin{array}{l}\text { Log }(1+b l a c k \\
\text { market premium) }\end{array}$ & & & & $\begin{array}{l}-0.0165 \\
(0.0049)\end{array}$ & & $\begin{array}{c}-0.0155 \\
(0.0047)\end{array}$ & \\
\hline $\begin{array}{l}\text { Sub-Saharan } \\
\text { African Dummy }\end{array}$ & & & & & $\begin{array}{l}-0.0118 \\
(0.0062)\end{array}$ & $\begin{array}{c}-0.0124 \\
(0.0058)\end{array}$ & \\
\hline \multirow[t]{2}{*}{$\begin{array}{l}\text { Latin American } \\
\text { Dummy }\end{array}$} & & & & & $\begin{array}{l}-0.0163 \\
(0.0058)\end{array}$ & $\begin{array}{l}-0.0142 \\
(0.0055)\end{array}$ & \\
\hline & & & & & & & $\begin{array}{c}0.0225 \\
(0.0425)\end{array}$ \\
\hline $\begin{array}{l}\mathrm{R}^{2} \text {, Individual } \\
\text { periods } \\
\text { (no. obs.) }\end{array}$ & $\begin{array}{ll}0.34 & (69) \\
0.25 & (69)\end{array}$ & $\begin{array}{ll}0.36 & (69) \\
0.28 & (69)\end{array}$ & $\begin{array}{ll}0.39 & (69) \\
0.29 & (69)\end{array}$ & $\begin{array}{ll}0.50 & (69) \\
0.25 & (69)\end{array}$ & $\begin{array}{ll}0.39 & (69) \\
0.37 & (69)\end{array}$ & $\begin{array}{ll}0.39 & (69) \\
0.37 & (69)\end{array}$ & $\begin{array}{ll}0.38 & (69) \\
0.30 & (69)\end{array}$ \\
\hline
\end{tabular}

Notes: See Table 1 . 
Table 4. FDI and Per Capita Growth: Instrumental Variables Eatimation

\begin{tabular}{|c|c|c|c|c|}
\hline \multirow[b]{2}{*}{ Regression Number } & \multicolumn{3}{|c|}{ Coeffictent } & \\
\hline & 4.1 & 4.2 & 4.3 & 4.4 \\
\hline Istimation method & 3SLS & 3SLS & 2 SLS & $2 S L S$ \\
\hline Investment Rate & & $\begin{array}{c}0.1236 \\
(0.0328)\end{array}$ & & $\begin{array}{c}0.0795 \\
(0.0441)\end{array}$ \\
\hline $\log (\operatorname{In} 1 t 1 a 1$ GDP) & $\begin{array}{c}-0.0085 \\
(0.0042)\end{array}$ & $\begin{array}{l}-0.0127 \\
(0.0040)\end{array}$ & $\begin{array}{l}-0.0101 \\
(0.0042)\end{array}$ & $\begin{array}{c}-0.0122 \\
(0.0041)\end{array}$ \\
\hline Schooling & $\begin{array}{c}0.0071 \\
(0.0045)\end{array}$ & $\begin{array}{c}0.0064 \\
(0.0042)\end{array}$ & $\begin{array}{c}0.0122 \\
(0.0050)\end{array}$ & $\begin{array}{c}0.0116 \\
(0.0049)\end{array}$ \\
\hline Govern't Cons. & $\begin{array}{l}-0.0837 \\
(0.0331)\end{array}$ & $\begin{array}{c}-0.0725 \\
(0.0307)\end{array}$ & $\begin{array}{c}-0.0477 \\
(0.0383)\end{array}$ & $\begin{array}{c}-0.0352 \\
(0.0372)\end{array}$ \\
\hline FDI & $\begin{array}{c}-1.6128 \\
(0.8448)\end{array}$ & $\begin{array}{c}-2.0155 \\
(0.8088)\end{array}$ & $\begin{array}{c}-1.4074 \\
(2.2714)\end{array}$ & $\begin{array}{c}-1.9083 \\
(2.2957)\end{array}$ \\
\hline FDI * School & $\begin{array}{c}1.3466 \\
(0.6364)\end{array}$ & $\begin{array}{c}1.3744 \\
(0.6030)\end{array}$ & $\begin{array}{c}1.7413 \\
(1.2551)\end{array}$ & $\begin{array}{c}1.8171 \\
(1.2148)\end{array}$ \\
\hline $\log (1+B M P)$ & $\begin{array}{l}-0.0167 \\
(0.0050)\end{array}$ & $\begin{array}{c}-0.0158 \\
(0.0047)\end{array}$ & $\begin{array}{l}-0.0228 \\
(0.0077)\end{array}$ & $\begin{array}{l}-0.0207 \\
(0.0074)\end{array}$ \\
\hline Africa & $\begin{array}{l}-0.0192 \\
(0.0061)\end{array}$ & $\begin{array}{c}-0.0121 \\
(0.0058)\end{array}$ & $\begin{array}{l}-0.0143 \\
(0.0059)\end{array}$ & $\begin{array}{l}-0.0094 \\
(0.0063)\end{array}$ \\
\hline L . America & $\begin{array}{l}-0.0227 \\
(0.0059)\end{array}$ & $\begin{array}{l}-0.0161 \\
(0.0056)\end{array}$ & $\begin{array}{l}-0.0188 \\
(0.0061)\end{array}$ & $\begin{array}{l}-0.0153 \\
(0.0058)\end{array}$ \\
\hline $\begin{array}{l}R^{2} \text {, Individual } \\
\text { Periods (no. obs.) }\end{array}$ & $\begin{array}{ll}0.40 & (69) \\
0.31 & (69)\end{array}$ & $\begin{array}{ll}0.50 & (69) \\
0.32 & (69)\end{array}$ & 0.54 & 0.57 \\
\hline
\end{tabular}

Notes: The three-stage least squares (3sLS) techniques estimates a system of two equations, with the dependent variables for the decades 1970-80 and 1980-89. The 3sLs technique uses inttial and lagged values of FDI and a Bast Asian continental dummy as instruments. The two-stage least squares (2SIS) technique estimates a cross-section of countries for the period from 1975 to 1985 with a lagged value of FDI over 1970-74 and the East Astan dummy as instruments. 
Figure 1

Bffects of Foreign Direct Investment on Growth

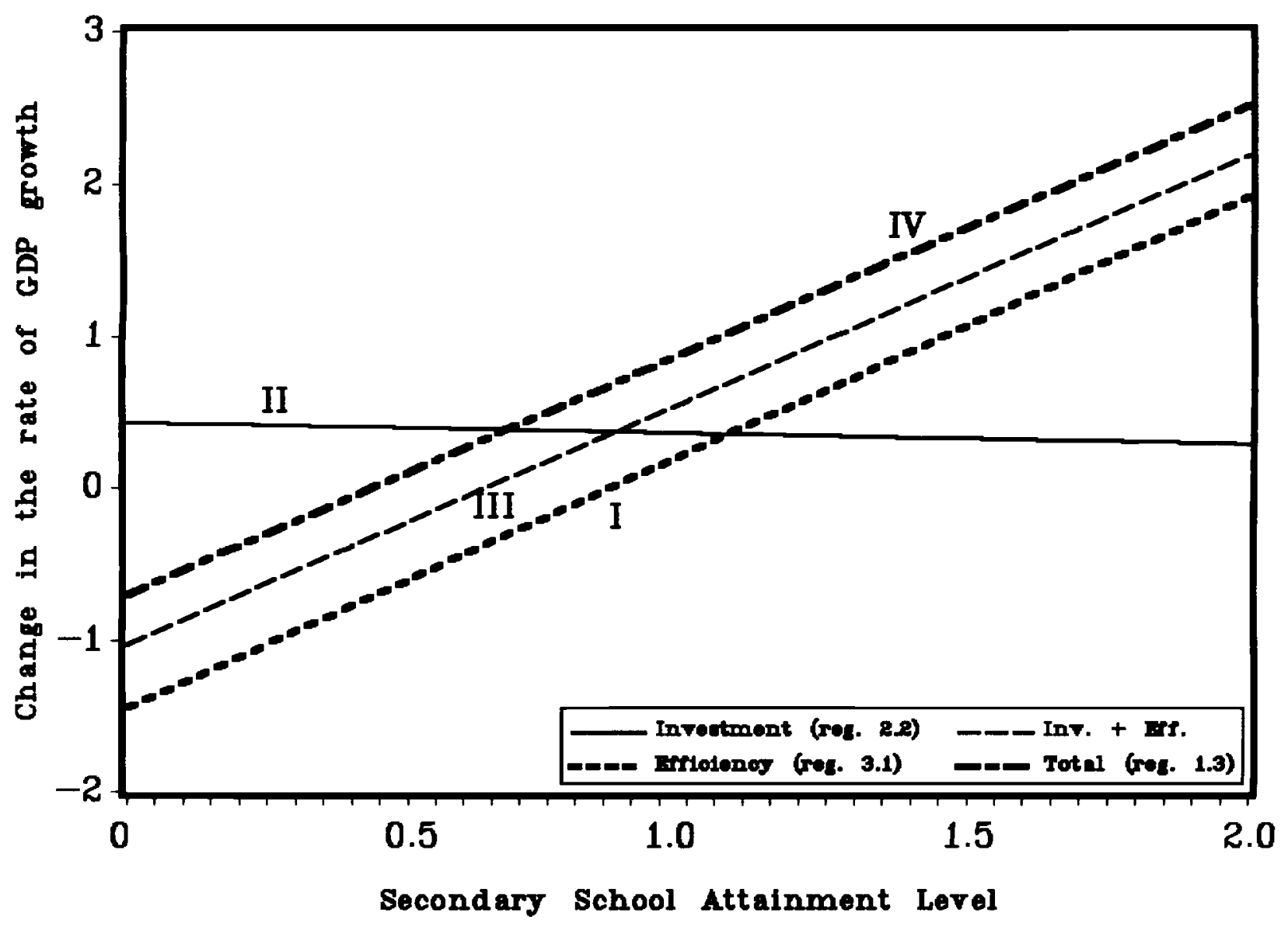

